\title{
Correction to: Stress as Offense to Self: a Promising Approach Comes of Age
}

Norbert K. Semmer ${ }^{1}$ • Franziska Tschan ${ }^{2}$ • Nicola Jacobshagen ${ }^{1}$ • Terry A. Beehr ${ }^{3}$ - Achim Elfering ${ }^{1}$ • Wolfgang Kälin ${ }^{1} \cdot$ Laurenz L. Meier $^{2}$

Published online: 5 February 2020

(C) Springer Nature Switzerland AG 2020

\section{Correction to: Occup Health Sci https://doi.org/10.1007/s41542-019-00041-5}

By Norbert K. Semmer \& Franziska Tschan \& Nicola Jacobshagen \& Terry A. Beehr \& Achim Elfering \& Wolfgang Kälin \& Laurenz L. Meier was originally published Online First without Open Access. After publication in volume 3, issue 3, page205238, the authors decided to opt for Open Choice and to make the article an Open Access

The online version of the original article can be found at https://doi.org/10.1007/s41542-019-00041-5

\author{
Norbert K. Semmer \\ Norbert.semmer@psy.unibe.ch \\ Franziska Tschan \\ Franziska.tschan@unine.ch \\ Nicola Jacobshagen \\ Nicola.jacobshagen@psy.unibe.ch \\ Terry A. Beehr \\ beehr1ta@cmich.edu \\ Achim Elfering \\ Achim.elfering@psy.unibe.ch \\ Wolfgang Kälin \\ Wolfgang.kaelin@psy.unibe.ch \\ Laurenz L. Meier \\ laurenz.meier@unine.ch
}

1 Department of Psychology, University of Bern, Fabrikstr. 8, 3012 Bern, Switzerland

2 Institut de Psychologie du Travail et des Organisations, University of Neuchâtel, Rue Emile-Argand 11, 2000 Neuchâtel, Switzerland

3 Central Michigan University, Sloan Hall 233, Mount Pleasant, MI 48859, USA 
publication. Therefore, the copyright of the article has been changed to (C) The Author(s) [Year] and the article is forthwith distributed under the terms of the Creative Commons Attribution 4.0 International License (http://creativecommons.org/licenses/by/4.0/), which permits use, duplication, adaptation, distribution and reproduction in any medium or format, as long as you give appropriate credit to the original author(s) and the source, provide a link to the Creative Commons license, and indicate if changes were made. 